\title{
'The communication networks used by special librarians in solo and small libraries'
}

by

\section{Nathan Burgess}

Submitted to the School of Information Management,

Victoria University of Wellington

in partial fulfilment of the requirements for the degree of Master of Information Studies 


\section{Abstract}

This study is an exploration of how isolated special librarians communicate with other professionals in the library field. It examines the means in which they connect with librarians for professional development and social reasons; the value they place on this interaction; and the barriers that hinder this communication. The qualitative study used semi-structured, in-depth interviews with a representative sample of seven special librarians in New Zealand. The specific population was professionals at special libraries with either a solo staff member or a very small staff.

There were several common themes among the interviews. Most interviewees were members of at least one professional library association such as LIANZA, but were more likely to be active in groups that were targeted at their field or at special librarians. When faced with a need for information, advice, or collaboration, the librarians interviewed were most likely to call upon colleagues they had met or worked with in the past, rather than an organised network or purpose-created group. There were several barriers identified that kept librarians from communicating with others, being active in the library field, and engaging in professional development activities. These included lack of support from their managers, lack of support from professional associations, feelings of isolation, and personal responsibilities such as raising a family.

The common concerns raised by the special librarians could be taken into consideration by professional associations, organisers of communication networks, and the librarians’ managers. For a clearer picture of special librarians' communication habits, a quantitative survey could be conducted, with survey questions informed by the results of this study.

Keywords: libraries; special librarians; solo librarians; communication; networking; isolation 


\section{Introduction}

Librarianship is a collaborative profession - the sharing of information is at its core. Through a variety of means, librarians discuss the many changes and challenges they deal with, and work together to find solutions. Joining a professional organization and attending conferences and workshops are formal ways to stay active in this ongoing conversation, while conversing with co-workers and other fellow librarians about professional issues is more informal. For those who work in libraries with several librarians on staff - or in large metropolitan library systems that can have dozens or even hundreds of professionals among their ranks - it is unlikely they will feel isolated from the library field, simply because they are surrounded by other librarians. The same cannot be said for those who work in small-staff and solo libraries. As the literature review will show, those in small branches, rural areas, schools, and special libraries can easily feel cut off from their peers.

Small staff and isolation from peers are common in special libraries, which are libraries that are part of a 'commercial firm, private association, government agency, non-profit organization, or special interest group,' rather than a public library or university library (Reitz, 2012). The scope of a special library's collection is typically narrower but deeper than public or academic libraries, and they primarily serve the information needs of their organization's staff.

Advice articles aimed at special librarians in solo and small libraries often warn about 'professional isolation' (St Clair \& Williamson, 1992). This is defined as 'the unpleasant experience that occurs when a person's network of social relations at work is deficient in some important ways' (Adapted from Peplau and Perlman and cited in Dussault, Deaudelin, Royer, \& Loiselle, 1999, p. 943). For special librarians, the deficiency may be that, despite the size of the organization and the number of nonlibrary organisational staff they see regularly, they have few or no co-workers with whom they can discuss library-related issues, learn skills or receive mentoring. On the other hand, many special librarians value the independence they have, including the ability to self-select their network of colleagues. Determining the methods special librarians choose to communicate with other librarians for formal or informal purposes, and the barriers that hinder this communication, can help the library profession to ensure that this valuable subset is not overlooked. 


\section{Research aim}

The aim of this study is to gain a better understanding of the networking habits of special librarians who work in an isolated capacity, especially solo or small-staff libraries. Specifically, it explores how these special librarians keep informed of changes in the library field and stay connected to other librarians, as well as what barriers keep them from doing so. The research questions relating to this aim are identified in the methodology.

\section{Literature review}

There have been very few studies published that deal with communication habits of special librarians who work in solo or small libraries, and none in recent years. Books and articles on the topic typically take the form of observations and advice rather than studies. This literature review will examine sources on librarians’ networking habits; attitudes towards and involvement with conferences, professional associations, and mentoring programmes; effects of professional isolation in similar fields, and first-hand advice for special librarians, especially solo librarians.

\section{Networking habits of librarians}

Bottorff, Glaser, Todd and Alderman (2008) explored the communication and networking habits of librarians in academic library systems. They described this area of research as of great interest but with little actual study. They sought to determine whether or not librarians in branch libraries feel a greater sense of professional isolation than those at main campus libraries. Branch librarians felt they had fewer networking opportunities with colleagues within their organization, largely due to lack of time, transportation options, and availability for social functions. They also felt they had less opportunity for professional development. Those who said they frequently communicated with other librarians were less likely to feel isolated, while those who worked at libraries with three or fewer librarians were more likely. Though staff sizes are often similar, there are some differences between branch librarians and special librarians. As part of a university library they had networking opportunities within their own organisation that independent special librarians do not, and while special librarians' managers are often unfamiliar with library operations, the same is less likely for the branch librarians. If the special librarians to be studied have similar comments 
about their networking habits, it may indicate that whether or not the host organisation is library-oriented is less important a factor than the isolating elements of distance and low contact with fellow librarians.

An older study directly explored the networking habits of special librarians (Murphy, 1976). Representatives of Special Libraries Association chapters were surveyed about what formal networks their chapter members were involved in, and as such the survey does not address informal networking. The survey asked about involvement in 20 different types of networks. The most common types of networks involved shared access to resources and catalogues, such as "reciprocal borrowing privileges”, “expanded interlibrary loan service”, and "union catalogs or lists”. When discussing formal networks in the modern age, it may be of interest to compare the results to Murphy's list and see which network types are still in use, and whether today's special librarians deem them more or less important than those of the '70s.

\section{Conferences, professional associations and mentoring programmes}

Conferences are an important form of professional networking, and for special librarians they may be one of the only ways to spend face-to-face time with colleagues. Vega and Connell (2007) surveyed a variety of librarians to determine their motivations for attending conferences. The top reasons for attending were found to be professional rejuvenation and networking with other librarians. However, these results were not universal - men and older librarians were less likely to go to conferences to feel energized about their careers, and reference librarians had a negative correlation with networking as a motivation. A review of the study points out some inconsistencies in the demographic portions of the survey questions and how they are discussed in the findings, which suggest the survey methodology could have been further refined (Özek, 2009). Though Vega and Connell did not focus on special librarians in the sample, the value special librarians place on conferences will factor into an overall study of their communication methods and habits.

Davidson and Middleton’s (2006) survey looked at professional library associations and the role they play in the professional development and mentoring of science librarians, who often work in small branch libraries or special libraries with very few staff. The main drawback, as identified by the authors, was that participation was solicited chiefly through professional library association distribution lists and through 
direct invitation to science librarians at certain academic institutions. As a result the sample was biased towards academic librarians and those active in professional associations, while special librarians at, for example, commercial engineering firms or government departments may have been left out if they were not members of the right associations. Networking and professional development were overwhelmingly cited as the most important benefits of membership in a professional association. Solo science librarians considered professional associations crucial for keeping up with the field despite the difficulties involved. However, this study focused primarily on professional associations for science and technology specialist librarians. Generalised associations, such as the American Library Association, were not counted, though the study acknowledged that some of the associations named in their survey were special interest groups within these larger associations. It is unknown whether all survey respondents were members of the general organisations, or if so, how they valued their membership. In New Zealand, Library and Information Association of New Zealand Aotearoa (LIANZA) is the best-known generalised library association, complemented by special interest groups devoted to special librarians and librarians in specific fields. It may be valuable to determine how special librarians in New Zealand value professional associations, both specialised and general in nature.

Davidson and Middleton (2006) also asked their survey participants about professional development guided by a mentor, such as a more experienced librarian paired with a novice librarian through a professional association. They found that many science librarians do not know about or take advantage of organised mentoring programmes, and that mentoring was more likely to be informal. Hicks (2012) also studied mentoring in a case study of an online forum for Latin American studies subject librarians. These librarians worked at institutions of varying sizes, but were often the only ones involved in Latin American Studies at their organisations - another form of professional isolation. Though the field itself has seen steady growth, training for librarians serving that field has been sparse. Hicks attempted to alleviate this problem with La Cuna, a social networking group intended to connect mentors and younger librarians. Hicks stated that though the site's mission was to provide mentoring, it seemed to be used more as a discussion forum, as those who she had envisioned as mentors were often asking for assistance themselves. In this case, communication amongst a specialised community of librarians was occurring, but the goal of facilitating 
mentoring was not as successful as expected because the community redefined its own purpose.

\section{Professional isolation in other fields}

Employees who telecommute share similarities with special librarians in small and solo libraries, as both rarely work alongside colleagues who are in a similar role. Cooper and Kurland (2002) interviewed telecommuting and non-telecommuting employees and their managers at two private and two public organizations. The study found that the isolation of telecommuting limited access to employee development activities, specifically interpersonal networking, informal learning and mentoring. Most librarians in small or solo special libraries differ from telecommuting employees in that they are physically present in their organization - their isolation is not from work colleagues or people in general, but from other librarians. This suggests that there is not a lack of interpersonal networking for the librarians, such as social events, camaraderie or 'water-cooler' chat. However, the lack of the other two employee development activities - informal learning and mentoring - are likely applicable. Library-related informal learning - gaining important information or skills through casual conversation with and observation of colleagues - will not be easy to acquire with no other librarians present. And if the librarian is the only member of the library profession in the organization, their manager or other experienced employees will be ill-equipped to mentor them in librarianship.

Another study of professional isolation in telecommuters sought to link professional isolation to specific job outcomes (Golden, Veiga, \& Dino, 2008). It was found that telecommuters who felt professionally isolated were more likely to have lower job performance, and this correlation was strongest among those who spent a great deal of time telecommuting and had limited face-to-face interaction. While the previously stated caveats regarding the differences between telecommuters and special librarians still apply, these findings suggest the possibility that job performance can be affected by isolation from colleagues. Professional isolation was determined to be positively correlated with occupational stress in a survey of Canadian teachers, especially stress related to poor relations with colleagues, administrators and parents (Dussault et al., 1999). Mentoring programmes, peer coaching, and support groups were recommended by the authors as potential means of alleviating this stress. If special 
librarians' isolation leads to occupational stress, that will impede them from performing to the best of their ability, which is a concern for them, their organisations, and the greater library field. However, the role of a special librarian is not identical to that of a telecommuter or teacher, so that aspect of the role must be assessed on its own merits.

\section{General advice for solo/special librarians}

Of the few books published on solo or 'one-person' libraries, professional isolation and communication are regular topics. To alleviate isolation, St Clair and Williamson suggest networking with non-librarian 'advisors', such as co-workers who are sympathetic to the goals and challenges of the solo librarian (1992, p. 18). They also suggest networking with other librarians through professional associations, inter-library networks (i.e. interloan arrangements), and personal contacts. The Essential OPL, 19982004 summarises articles from The One-Person Library newsletter, which has featured several articles with advice from solo librarians on the subject of networking (Siess, 2005). Summarised in the compilation is an article by Bert Washington with advice on setting up a regional discussion group (pp. 157-158), two editorials from Judith Siess about why solo librarians should attend conferences and how they can convince their managers to support them (pp. 158-163), and tips from Jill Ann Hurst on effective ways to network with fellow librarians and vendors at conferences (pp. 163-166). Finally, How to Thrive as a Solo Librarian includes articles on professional development and growth. Hornung discusses how to approach 'indifferent' managers to garner support for professional development, and lists ideas for activities that contribute to continued learning (Hornung, 2012). Mitchell discusses distance education programmes and their usefulness to solo librarians, social networks and blogs as communication methods, and mentoring opportunities, both in the physical and virtual worlds. She also emphasises the importance of writing, whether it's in a journal or a personal blog, as an active means of communication with the library field (Mitchell, 2012).

Advice articles in newsletters, magazines and journals provide some encouragement and creative networking ideas for special librarians in small and solo libraries. Bordelon (2008) recommends networking through the patrons, for example keeping in touch with patrons who may be able to connect with new information or resources. Karabush and Pleviak (2011) say a network of colleagues can contribute to a pool of resources - for example, creating videos for patrons and posting them to a group 
wiki. They can also deal more effectively with vendors, share information that may influence each organization's policies, and help ease each others' feelings of being overwhelmed. School librarians often work in a solo capacity, though they are administratively connected to their colleagues, and Nickel (2011) describes how video and web conferencing was used in his school district to hold regular meetings while overcoming geographic barriers. The school librarians also collaborated on the creation of a course for educational credit that gave them the opportunity to spend time together while developing professionally. Finally, a corporate solo librarian interviewed for an article says that having to take a more active role in networking makes her feel even more connected to the library field than she otherwise would, and that she considers the colleagues she sought out to be just as much her workmates as those with whom she shares a building (Siess, 1999, p. 34).

\section{Summary}

These articles suggest that professionals in working environments similar to those of special librarians in small and solo libraries may seek out colleagues through various means such as online communities, conference attendance, and joining professional organisations. Some networking was motivated by career-advancement and project-related goals such as professional development, learning new skills, and collaboration. Other networking was emotionally-driven, such as reducing feelings of isolation and reenergizing passion. Mentoring is often raised as a reason for networking, but the studies found that while a lack of mentoring opportunities is an issue for isolated professionals, the networks were rarely used for that purpose by librarians. Feeling isolated and distant from others in the same profession can lead to stress and negative implications, as was seen in both library and non-library settings. Many of these issues have been raised by individual special librarians and solo librarians based on their own experiences.

\section{Methodology}

An assessment of the available literature reveals that librarians have many common methods of communicating as a profession, whether at conferences, online, or through other channels. Special librarians are rarely represented in studies in studies of networking amongst librarians, but other literature suggests that networking can be 
difficult for this group. This is supported by studies on isolation in professions with similar working conditions. Therefore, research questions for this study were derived by assessing the available literature and identifying gaps, or areas of study suggested by the non-research-based articles.

This study seeks to explore the nature of networks that professionally isolated special librarians participate in to stay connected to the library field, and the value the librarians place on those networks. It will seek to discover:

1. How special librarians in solo or small-staff libraries communicate with other librarians;

2. How important it is to them to communicate with other librarians and stay active in the library field;

3. What barriers exist that keep them from communicating with other librarians.

A qualitative approach aims to gain a deeper understanding of a phenomena in a natural setting (Leedy \& Ormrod, 2012) by exploring a limited number of cases, discovering and analysing themes, and drawing conclusions about a population. Qualitative research is especially useful in areas where little prior research has been completed and variables are unknown - exploring a few cases in great depth will gain insights and verify assumptions, thus providing a greater foundation for wider-scale research (Leedy \& Ormrod, 2012). Given the lack of research in the area of networking habits of special librarians, this approach allows the researcher to gain a clear picture based on a small but representative sample.

Quantitative methods could also have been employed to explore the research questions in this study, but the aspects studied would have been very different. In quantitative methods data is expressed as variables that can be quantified and measured (Punch, 2005). For this research project a descriptive quantitative method, such as a survey, would likely reach more respondents and allow for a clearer picture of special librarians in New Zealand. The chief concern is that, with literature so restricted on this subject, survey questions would not be well-informed and a limited scope of answers would not allow respondents the flexibility to fully describe their experiences.

This study utilised semi-structured in-depth interviews. The analysis allowed the open-ended responses to the questions to define the parameters of the conclusions. With 
semi-structured interview questions, information that the interviewer did not anticipate - such as uncommon or innovative networking methods - can be brought into the conclusions, and questions can be added or removed as appropriate based on the interviewees’ responses (St Clair \& Williamson, 1992). The interview format was set up with a basic set of questions followed by another set that could be repeated for each mode of communication the librarian participates in, with questions able to be removed if they were previously answered. The intention was to allow each librarian to tell their own story, but within a framework that would make it easy to highlight common themes.

Other interview types were considered, such as structured interviews, in which all interviewees are asked standardised questions with preset possible answers, and unstructured or ethnographic interviews, which are open-ended and take the form of a conversation with no preselected questions (Punch, 2005). In this situation structured interviews - like qualitative surveys - were seen as too restrictive, with the potential to limit the details and experiences special librarians may have to share. Conversely, unstructured interviews had the potential to be too divergent from interview to interview, making it difficult to find common themes.

\section{Ethical considerations}

Approval from the Human Ethics Committee at Victoria University of Wellington's School of Information Management was secured before potential participants were contacted. Information sheets and consent forms (see appendix) were prepared and approved for distribution to participants. Every attempt has been made to ensure the data as presented in this paper keeps the identities of the participants confidential.

All interviews were recorded and transcribed by the researcher. The audio files and transcription text files will be held in a password-protected file, and the interview notes and signed consent forms kept in a locked cabinet, until two years after the completion of the research. Recordings, transcripts and notes will be destroyed at this date. Participants were given copies of their transcripts to review and correct any factual errors in transcription. 


\section{Population and sample}

The population is librarians currently employed at special libraries in New Zealand, where those libraries consist of a small staff (less than three) or a single staff member. These libraries are often part of an organization, such as a commercial business or non-government organisation (NGO), but not administratively part of a library network, or an organisation whose main focus is providing library services. These librarians are therefore professionally isolated in terms of their distance from other librarians, as opposed to isolated from all other co-workers, as is the case with telecommuters. The size of this population is unknown, but can be estimated - there are over 200 libraries in the Directory of New Zealand Libraries that could be considered special libraries ${ }^{1}$ (National Library of New Zealand, 2013), while the 2006 edition of New Zealand Contacts in Libraries and Information Services details nearly 250 special libraries, of which over 130 list a full-time equivalent staff of three or less ${ }^{2}$ (Contacts Unlimited, 2006). For this qualitative interview-based study, the proposed sample size was 8-10 participants, with a final sample size of seven.

Potential participants were identified through the Directory of New Zealand Libraries (National Library of New Zealand, 2013) and New Zealand Contacts in Libraries and Information Services (Contacts Unlimited, 2006). This method was preferred over utilising established networks of special librarians, such as LIANZA's special interest group Special Libraries and Information Services (SLIS), to avoid oversampling those networks. New Zealand Contacts in Libraries and Information Services was older and more likely to be out of date than the Directory, but it had the benefit of including approximate staff sizes in the form of full-time equivalents. By reviewing the sections of these resources for special libraries, twelve libraries that appeared to be solo or small staff libraries were selected. This "first wave" of potential participants was intentionally chosen to have a variety of specialist subjects and geographic locations, with both urban and rural areas. The intention was that a second dozen potential participants would be selected if responses to the first wave were insufficient, but this was not necessary.

\footnotetext{
${ }^{1}$ This estimate excludes public and academic (university and tertiary-level) libraries, but includes government libraries.

${ }^{2}$ Of the special libraries that did not list staff FTE of three or less, some listed a larger staff size while others did not list a staff size at all.
} 
Potential participants were sent a form email describing the project and asking them to respond if they were interested in participating. Those who indicated an interest were given an information sheet and consent form. The original plan was to also send a questionnaire to collect data about their organisation, but this was instead discussed in the interviews.

Out of the twelve librarians approached, interviews were conducted with seven of them. All were from Auckland or Wellington - those from smaller towns in New Zealand did not respond or interviews could not be arranged. Six were solo librarians while the seventh was one of three in their library. Three were full-time librarians, while the remainder were part-time or split their role between their library and other duties such as records management. Five of the libraries were either health libraries or were in organisations that were health-related, though they did not provide health services; the other two specialised in art and history respectively. The size of the host organisations ranged from very small (less than five staff) to very large (over 2,500 internationally).

\section{Data collection}

Four interviews were conducted face-to-face, and the other three were done over the phone. These styles were preferred over email-based interviews due to the immediacy and spontaneity of the responses. Participants were also given the choice of conducting the interview through online video chat if they preferred, but none chose this option. Three of the face-to-face interviews were done at the participant's workplace, and the fourth in a public location as the participant was visiting from out of town. Each participant was provided with an information sheet and signed a consent form, to comply with the terms of the ethics committee's approval for this project.

The questions for the semi-structured interview were tested and refined with a pilot interview before being used for the study. They were broadly divided into three sections - general information about the participant's career, their current library and its host organisation; an evaluation of the participant's level of activity in and connection to the wider library field; and an evaluation of the library-related communication networks they participate in. The questions were designed to be flexible to allow the interviewer to drop unnecessary questions as needed, or avoid repeating information that the participant had discussed earlier on their own volition. After the interviews were 
completed, the recordings were transcribed by the researcher. The transcripts were notated for common themes and to compare and contrast answers.

\section{Limitations}

Potential biases or assumptions could stem from the researcher's role as a solo special librarian in a health-related field. The researcher therefore is a member of the population being studied and strove to remain objective during interviews, but acknowledges that a bias could have been present. The researcher presented himself as a student and not as a representative of his workplace, and had not previously met any of the participants.

The majority of the librarians who responded for interviews were from healthrelated organisations, which could limit the diversity of responses. It should be noted that within that group there was a variety of organisations represented - aside from health service delivery, there was health-related professional association, an historical interest society, and an engineering firm that specialised in medical equipment. Many of the librarians who did not respond were from libraries that were not health-related. This majority could be a coincidence, or could be indicative of the number of health-related special libraries operating in New Zealand.

\section{Results}

The librarians interviewed were asked questions about their methods and means of communication with other librarians outside their organisation, what motivated their communication, and how important these communication networks were to their work lives. They discussed the formal networks to which they belong: these were groups that were deliberately designed for the purpose of connecting members to facilitate discussion and collaboration. The participants also discussed their informal networks, which are any means of communication that arise organically rather than by purpose, or do not require formal membership. Finally, in response to a question asking how they communicate, many were eager to discuss the barriers that kept them from communicating with their peers. These included feelings of isolation and their causes; the relationship with their host organisation, including the level of support they received and their other duties; and other barriers, such as personal demands that limited their time and motivation. 
Interestingly, every librarian interviewed had spent all or most of their career in special libraries. At most, some had spent a small amount of time in public libraries or worked as a reliever, but not a significant percentage of their career. It is unknown if this was a coincidence, or if it is common among special librarians to avoid other areas of librarianship - perhaps these 'career' special librarians were simply more likely to respond to requests for interviews on this topic. They were at a variety of points in their careers - the longest had been a librarian for 50 years, while the shortest only seven but each of them rarely if ever deviated from special libraries as a career track. When asked for an overall assessment of their level of activity in the field of librarianship, six said they were not at all or not very active, and the seventh said they were moderately active.

\section{Formal networks}

Many of the librarians interviewed stated they were members of one or more professional associations. The associations mentioned can be put into one of three categories: those devoted to representing all librarians (i.e. LIANZA); those devoted to representing a subset of librarians, such as special librarians or those in a specific field (i.e. SLIS, HealthLib); and those devoted to another field of professionals, which librarians can belong and contribute to if they are serving that field. When asked to expand on their membership in library-related organisations and professional networks, five indicated they were members of LIANZA, while one said they had once been part of LIANZA's recently-introduced registration scheme but had to discontinue their registration due to company cutbacks on support for professional development. Four reported they were members of SLIS; a fifth said they had let their SLIS membership lapse, and being approached for this research project had reminded them to renew it. Many were members of networks specific to their library's field. Three were members of HealthLib, an interloan network and special interest group for health-related special libraries. One was a member of the New Zealand Federation of Disability Information Services, and one a member of an Australasian network of art librarians. Only one librarian reported not belonging to any library-related organisations or professional networks of any kind. Two librarians reported belonging to networks that aided professionals in other fields; these were a records management network run by Archives New Zealand, and a US-based online discussion group for engineers. 
Methods of communication facilitated by formal networks usually took one of two forms: attendance at conferences and workshops, and active or passive participation on email discussion lists administered by professional organisations. Six librarians mentioned reading discussion lists run by LIANZA, HealthLib, or other professional organisations. No one indicated that they were particularly active in responding, though some mentioned they occasionally responded if they felt they could contribute. Attendance at conferences, workshops, and study days was even less likely. One librarian said they 'haven't attended a conference in years', and likewise had not been able to attend HealthLib workshops, due to professional development cutbacks in their organisation. Four librarians said they only rarely attended conferences and workshops, and had not attended any recently. One librarian was active in conference planning and attendance within their specialised field, but did not consider going to general-purpose library conferences unless they happened to be very close geographically and/or featured a keynote speaker the librarian wanted to hear speak.

Opinions of library networks and professional organisations’ relevance to special libraries were not positive. Three librarians said LIANZA did not have much to offer special librarians and were too 'broad-based' and focused on public libraries. However, SLIS - LIANZA’s special interest group for special libraries - was mentioned positively by one librarian, who had worked on the SLIS committee in the past and said the network was 'really useful' to solo librarians.

Opinions were mixed regarding the relevance of communication networks that served specific fields. Two of the health librarians were critical of the special interest group HealthLib, saying it was too focused on District Health Board libraries and that its events such as workshops and study days were rarely relevant to non-DHB librarians. However, the art museum librarian described being 'heavily involved' in an Australasian art libraries organisation, including previously holding a leadership position and currently helping to organise a conference. They referred to the specialised group as their 'main focus' over a general interest group such as LIANZA, and admitted they were in a 'privileged position' that not all special librarians were in:

If you're working somewhere that doesn't have a lot of specialised librarians working in that area, there isn't a strong network to fall back on, so where do you go? What do you do? 
The librarians interviewed all seemed to agree that organisations and networks were more advantageous as their aims grew more specific: general library organisations were not useful; special library organisations were somewhat useful; organisations for librarians in a specific field were most useful.

\section{Informal networks}

Nearly all of the librarians interviewed said they were very likely to call upon their own informal network of colleagues if they had questions, needed opinions or recommendations, or were looking for collaborative partners. These colleagues were usually former coworkers, people met at conferences or other professional development activities, and people who were directly approached due to their position or reputation. This was often preferred over organised networks and user groups:

I'm constantly in contact with librarians for various things [...] There's definitely a community who are working with these sorts of collections [...] It's around content that the networks form, similar content you're dealing with on a day to day basis. (Librarian $C$ )

Other librarians commented that they preferred asking their peers on a one-to-one basis if they had a question or request, drawing on their prior relationships from previous jobs and those who they had met in the librarian community. Only one librarian did not feel they had the same social network to draw upon, saying they had one only one previous library job and had lost contact with former coworkers.

Regarding less formal means of communication, four librarians reported that they occasionally read library blogs and news sites. Many sites were overseas-based, but one librarian specifically cited the NZ-based "Finding Heroes” blog maintained by Sally Pewhairangi ${ }^{3}$ as a regular point of entry for library news. Two reported that they received emails from library-related listservs and occasionally contributed to the listserv; a third reported contributing to an engineering listserv in their capacity as a librarian with a patron base of engineers. Again, one librarian reported they did not read any library-related news or participate in online discussion groups, and had no interest in doing so due to other time commitments. Email was the preferred method of communication for the interviewed librarians. There was no mention made of using

\footnotetext{
${ }^{3}$ http://findingheroes.co.nz/
} 
other Internet-based communication means such as social media (i.e. Facebook or Twitter).

\section{Isolation as a communication barrier}

As most of the librarians interviewed felt they did not have access to as many communication options as those in larger libraries, they were asked about the barriers that kept them from being more active. Many of them described feelings of isolation:

It's much harder when you work on your own. You're in a bit of a vacuum really. (Librarian A)

Another librarian reported feeling 'out on a limb' due to the lack of fellow librarians they could count on for support or relief when taking leave.

Geographic isolation was a particular factor for one librarian, who worked very far from the city centre and found in-person participation difficult:

I think possibly if you were in a [public] library or an academic library you'd have a lot more connections, because special libraries - especially being out here - where do I go? I have to go into town for SLIS [meetings] and am fighting traffic to get there, and quite often can't get there on time. So I just tend to push them away [...] Being this far out is probably worse than just being a sole-charge. (Librarian B)

To this librarian, face-to-face contact was very important because it was so rare due to the geographical barrier, and online forms of communication were not seen as an equal substitute. Conversely, a librarian who was located in a city business district reported that being geographically close to other libraries provided opportunities for collaboration. The library was located in easy walking distance to a main branch of a public library that housed a special collection in a related field, and the librarian indicated they had a good relationship and frequent collaboration that was aided by the physical proximity.

Another factor that affected isolation was the level of support from the host organisation, which could take the form of the amount of funding available for professional development activities or simply allowing time for interactions with other librarians. About half of the librarians mentioned a lack of support for professional development at their organisations: 
A lot of special libraries, particularly like this sort of library, there's not much money, so you don't always have the latest technology available to you, and there's not a lot of money to go to conferences and stuff like that. (Librarian A)

The company has cut back on training which means my training like conferences, study days, attending anything has become just about zero [...]It's made me feel more isolated, because I can't carry on as before which was a lot more physical networking rather than just emailing or talking on the phone. (Librarian B)

This librarian had been through multiple organisational changes and had reported to a few different managers. The feeling of not being understood by a direct manager was a clear source of stress:

They pushed me over to [human resources], who had no idea what to do with me. No idea what a librarian does other than having books in the room. That was not good [...] Now I report to the VP of regulation and quality, which is better but still not brilliant because you don't have the rapport. (Librarian B)

A third librarian spoke in similar terms of a previous employer, saying that was 'the case with special libraries’.

However, the other half of the librarians mentioned some support from their organisations. One said they had a budget that allowed for some limited professional development, although travel costs were a barrier so the LIANZA conferences were only considered if they were in the same city as the library. Another librarian reported 'support and nagging' from a manager to participate in outside collaboration and professional development activities.

\section{Other communication barriers}

The importance of the library to the overall role of the person affected the importance of external library relationships. Two librarians split their role between managing the library and other duties for their organisation, one records management and the other publishing. The librarian/publisher reported a very low importance placed on the library in their organisation:

I don't spend an awful lot of time on the library. When I started I got a few more information inquiries, but there's a lot more online access to information now, I don't get as many [...]The fact that I'm a solo librarian in this office and a great 
deal of my work is doing other things, yeah, I just don't have much time for extra library interaction. (Librarian F)

The other librarian that reported a split role said only $10 \%$ of their job was libraryrelated, and the remainder of their time was spent on other records management duties. However, this librarian spoke of the value of SLIS to special librarians and their own seeking out of library-related information to keep a connection to the field, which is evidence that they placed some importance on the library side of their job despite the small amount of time dedicated to it.

Home life and other responsibilities were a barrier to more active involvement. Two of the librarians said they only worked part time so they could spend more time at home with their young children. One of them had recently restarted work after parental leave, and though they had renewed memberships in LIANZA and email discussion lists, they didn’t actively contribute often:

I've only just got back into it since I've got this job, and I've got to work out a way that the library can stay relevant and useful to people.(Librarian D)

The other working parent said they did not search for ways to stay active due to family commitments monopolising their time outside of work. Finally, another librarian indicated they were going to retire soon, and though they had previously been more active they were now slowing down because they had 'been there and done all that'.

\section{Summary}

The major themes that emerged through the results were that both formal and informal networks were utilized by the librarians to communicate with their peers in the library profession, to varying degrees. Informal networks and one-to-one communication were preferred over asking questions of a large group of unknowns, such as an email listserv. The special librarians tended to be members of generalised professional organisations (chiefly LIANZA) but did not consider them very relevant to their careers; more focused organisations had a more positive reception. The librarians face several and varying barriers to being more active in the field. The nature of their work was isolating, though not always in the same way - some felt that their host organisations did not support their professional development activities, while others 
cited physical barriers such as distance. For some it was a matter of choosing to focus on other commitments, such as their families.

\section{Discussion}

This research sought to discover how special librarians in small and solo libraries communicate with other librarians, how important it is for them to do so, and what barriers stop them from doing so. Despite the fact that their workplace can isolate them from librarian colleagues, special librarians in small or solo libraries do not always try to keep in contact with the greater library field. In fact, some special librarians are fully or mostly disconnected from the field, and though they may not be happy with this state of affairs, changing this activity level is not always desired or viewed as achievable. In the most extreme case, the librarian's other commitments and the lack of support from the organisation seemed to be the major factors contributing to this lack of motivation.

\section{How and why do they communicate?}

For most of the librarians interviewed, the most likely way they would seek help in answering questions, finding resources or looking for collaborative partners was through their networks of contacts, generally people they knew well or had met in person. For the most part, the librarians indicated that person-to-person contact was their most common and likely means of communication with other librarians, far more so than active participation in online groups or attendance at library events. This form of networking tends to be overlooked in the literature. While it is a natural tendency for people to build friendships with co-workers and others in their profession, it is also evident that many of the more formal networks of communication are not seen as particularly welcoming to special librarians. In addition, this study sample was made up of librarians who had spent all or most of their library career working in special libraries. If this trend is common across the field, special librarians could be left even more isolated as they would have fewer pre-existing relationships to add to their networks.

The results of the interviews were similar to those found by another study with librarians at small branch libraries. Lack of time and lack of opportunity for professional development activities were common themes between the special librarians interviewed 
and the branch librarians studied by Bottorff, Glaser, Todd and Alderman (2008). One librarian also reported geographic isolation, which fits with the branch librarians’ reports that transportation to events and social functions contributed to feelings of isolation. The size of the city where the librarian's workplace is located will affect these factors. Larger cities such as Auckland will likely have more libraries and librarians, especially in central business districts, but will also have more traffic issues. The other study on networking habits shows a shift in networking preferences over time (Murphy, 1976). A high value was once placed on networks that provided interloan, reciprocal borrowing, and cataloguing services to their members. While these are still important, as shown by the health librarians' membership in HealthLib which has an interlibrary loan system, the special librarians interviewed more often mentioned shared learning and exchange of information rather than library items when discussing their reasons for participating in networks. In fact, the communicative benefits of HealthLib to the interviewed librarians were often relating to the group's email discussion list rather than its resource-sharing functions.

Conferences were mentioned by the librarians as a potentially important form of networking, and often one that was unavailable to them. The value of face-to-face interaction that conferences facilitate, and the learning opportunities they offer, were reasons given for their importance. These advantages can reasonably be expanded to the workshops, study days, and similar opportunities for learning and networking that were mentioned by librarians, even if those events were not part of a larger conference. Vega and Connell (2007) described similar results among the librarians they surveyed. Those librarians also placed a high value on conferences as a means of rejuvenating interest in and excitement for one's library career. While the special librarians interviewed did not specifically mention this as a reason to attend conferences, it can be inferred they feel similarly through comments made about the disillusioning effect of being denied access to these learning opportunities.

The librarians' interaction with professional organisations were consistent with the results of Davidson and Middleton (2006). They found that professional organisations’ aims were to foster networking, professional development and mentoring, but the science librarians surveyed were largely only interested in the first two activities. Mentoring as a form of learning and communication with other librarians was not mentioned at all by any of the special librarians interviewed for this study. This 
resonates with other Hicks' (2012) conclusion that mentoring is not a priority for librarians in niche fields. This lack of value placed on mentoring is in contrast to literature exploring isolation in other professions, particularly telecommuters. Mentoring was one of three identified employee development activities that were lacking in availability to isolated telecommuting employees and was recommended as a means of alleviating stress in teachers (Cooper \& Kurland, 2002; Dussault et al., 1999).

\section{What are the barriers?}

During the course of the interviews the question participants were quite interested in answering was, "What are the barriers to more active involvement in the library field?” This serves as a corollary to the question of how special librarians communicate with their colleagues. In most cases, their initial response was that they don't do much, if anything, to communicate and stay active in the field. Most of them did go on to describe ways they communicated with other librarians, but had a low selfassessment of their activity due to the low intensity of their communication - for example, participating in email discussion lists occasionally rather than daily, or comparing their own level of activity to that of very active librarians they were aware of. The smaller, more casual means of communication - such as reading and occasionally contributing to email discussion lists - were not seen as significant when they assessed their own level of activity in the library field.

Many of the librarians reported not attending conferences, workshops, study days, and other professional development activities for a variety of reasons. The lack of resources and support from the host organisation was one reason. Some said they had previously been given funding to attend these events, but haven't recently - potentially due to the impact of worldwide economic difficulties in the last few years. One librarian indicated that changes in management directly impacted their ability to attend these events, describing how they began the role under a manager who provided for professional development opportunities, but after a reorganisation they were moved to managers who were less interested or less understanding of the library's role, which has resulted in reduced resources. Securing the permission and funding to attend these activities can be an almost-impassable barrier to special librarians if they must first expend the time and energy to convince their managers. 
Another reason for nonattendance was that the content was often seen as irrelevant to special libraries, focusing instead on the larger pools of public and academic librarians. LIANZA and its annual conference were frequently mentioned in conjunction with this problem, with some librarians mentioning that the presentations in the conference itself were rarely applicable to special librarians. One librarian did point out that some conferences would have workshops for special librarians happening at the same time, though the main events and presentations of the conference were clearly designed with public and academic librarians in mind. Organisations with a narrower focus, especially networks aimed at special librarians or librarians in a particular field, were more likely to generate interest among the librarians. However, this was not a guarantee as HealthLib, a network for health special librarians, was seen by some members as primarily focused on librarians employed by District Health Boards.

There may be some special librarians who are very unlikely to ever be active in the profession outside of their own workplaces. Those who had extensive family commitments and those who worked part-time or split their role with non-library duties were particularly dismissive of the idea that they could devote extra time to attending events, participating in discussions or even thinking about libraries outside of their workplace. The perception that special librarians are ignored or marginalised by library associations such as LIANZA can reinforce the idea that attempting to be active is not a valuable use of their time. SLIS can fill the role of being an association for special librarians, but while it is valuable for special librarians to communicate with each other, isolating special librarians from the wider library field will contribute to the perception that LIANZA is only for public and academic librarians, as expressed by the interview participants.

\section{Conclusion}

This research demonstrates that informal networks are key to addressing special librarians' communication needs. These networks largely consist of former colleagues and contacts from professional development activities such as workshops and conferences. However, as interviewees indicated these activities were difficult to engage in due to barriers including distance, lack of funding, lack of time, a perceived lack of relevance to their role, and a perceived lack of value placed on special libraries by the wider library profession. These barriers must be recognised as legitimate, further 
understood, and addressed by the rest of the profession in collaboration with special librarians. Helping special librarians engage in professional development activities will improve their ability to keep informed of changes in the library field and stay connected to other librarians, through strengthening their informal networks and encouraging use of formal networks, to the benefit of the entire field.

For future study on this topic, the responses and themes could inform the basis of a questionnaire for a wide-scale survey of special librarians, especially those in solo or small-staff libraries. This would provide a clearer picture of what special librarians as a group do to communicate with other librarians by determining how widespread the barriers identified in this study are, and by showing what the most popular communication methods are amongst a larger sample of the population. This study and future studies based on it can be used to help library organisations such as LIANZA interact with and include special librarians to a more productive degree. This could take the form of outreach initiatives, increased support for special interest groups and fieldspecific communication networks, and programmes designed to help special librarians improve their relationship with their host organisation and managers. Finally, the lack of mentoring among special librarians is an area that could benefit from further study or reflection, as it is something identified as advantageous in professions that have similarities to special librarianship. 


\section{References}

Bordelon, B. (2008). Networking strategies for business and economics librarians. Journal of Business \& Finance Librarianship, 13(3), 371-377. doi: $10.1080 / 08963560802183294$

Bottorff, T., Glaser, R., Todd, A., \& Alderman, B. (2008). Branching out: communication and collaboration among librarians at multi-campus institutions. Journal of Library Administration, 48(3/4), 329-363. doi: 10.1080/01930820802289391

Contacts Unlimited. (2006). New Zealand Contacts in Libraries and Information Services (5th ed.). Picton, NZ: Contacts Unlimited Ltd.

Cooper, C. D., \& Kurland, N. B. (2002). Telecommuting, professional isolation, and employee development in public and private organizations. Journal of Organizational Behavior, 23, 511-532. doi: 10.1002/job.145

Davidson, J. R., \& Middleton, C. A. (2006). Networking, networking, networking: the role of professional association memberships in mentoring and retention of science librarians. Science \& Technology Libraries, 27(1-2), 203-224. doi: 10.1300/J122v27n01_14

Dussault, M., Deaudelin, C., Royer, N., \& Loiselle, J. (1999). Professional isolation and occupational stress in teachers. Psychological Reports, 84(3 Pt 1), 943-946.

Golden, T. D., Veiga, J. F., \& Dino, R. N. (2008). The impact of professional isolation on teleworker job performance and turnover intentions: does time spent teleworking, interacting face-to-face, or having access to communicationenhancing technology matter? Journal of Applied Psychology, 93(6), 1412-1421.

Hicks, A. (2012). Analyzing La Cuna: New Approaches for Mentoring in Professional Associations. Collaborative Librarianship, 4(1), 2-13.

Hornung, E. (2012). Chapter 12: Continuing Professional Development. In C. Smallwood \& M. J. Clapp (Eds.), How to Thrive as a Solo Librarian. Lanham, MD: Scarecrow Press.

Karabush, C., \& Pleviak, P. (2011). Talk Me Off the Ledge: Surviving Solo Librarianship. Knowledge Quest, 40(2), 48-53. 
Leedy, P. D., \& Ormrod, J. E. (2012). Practical Research: Planning and Design (10th ed.). USA: Pearson Education.

Mitchell, K. (2012). Chapter 13: Professional Growth for the Solo Librarian. In C. Smallwood \& M. J. Clapp (Eds.), How to Thrive as a Solo Librarian. Lanham, MD: Scarecrow Press.

Murphy, M. (1976). Networking practices and priorities of special and academic librarians: a comparison. Occasional Papers, 126.

National Library of New Zealand. (2013). Directory of New Zealand Libraries [downloadable spreadsheet]. Retrieved 29 May 2013, from http://natlib.govt.nz/files/tepuna/Library-Directory-latest.xls

Nickel, R. (2011). Solo Librarians Working Collaboratively. Knowledge Quest, 40(2), 40-43.

Özek, Y. H. (2009). Rejuvenation and Networking Motivates Librarians to Attend Conferences. Evidence Based Library and Information Practice, 4(4), 78-80.

Punch, K. F. (2005). Introduction to Social Research: Quantitative and Qualitative Approaches (2nd ed.). London: Sage Publications, Inc.

Reitz, J. M. (2012). Special library. ODLIS: Online Dictionary for Library and Information Science. Retrieved 14 October, 2012, from http://www.abcclio.com/ODLIS/odlis_s.aspx\#speciallibrary

Siess, J. A. (1999). Flying solo: librarian, manage thyself. American Libraries, 30(2), $32-34$.

Siess, J. A. (Ed.). (2005). The Essential OPL, 1998-2004: The best of Seven Years of The One-Person Library: A Newsletter for Librarians and Management. Lanham, MD: Scarecrow Press.

St Clair, G., \& Williamson, J. (1992). Managing the New One-Person Library. London: Bowker-Saur.

Vega, R. D., \& Connell, R. S. (2007). Librarians’ attitudes toward conferences: a study. College \& Research Libraries, 68(6), 503-515. 
Appendix

Information Sheet

Consent Form 


\section{Participant information sheet for 'The communication networks used by special librarians in solo and small libraries'}

\section{Researcher: Nathan Burgess, Victoria University of Wellington}

I am a Masters student in the School of Information Management at Victoria University of Wellington. As part of this degree I am conducting a research project to examine the ways in which librarians who work in small or solo special libraries communicate with others in the library field. The University has granted ethics approval for this project.

I am inviting special librarians who work as the only librarian in their organization, or one of a small library staff, to participate. The libraries may be independent or embedded in an organisation, but not administrated as part of a network (e.g., a public library consortium). This subset of the librarian community is underrepresented in existing studies on networking habits.

Regarding communication habits, I am interested in the ways in which these librarians discuss library-related issues with others outside their organisation. I would like to schedule an interview with you at a mutually agreed-upon time and place. This can be face-to-face, by phone, or using teleconference software such as Skype - whichever you are most comfortable with. This interview will be recorded and transcribed, and should take between 30 and 45 minutes to complete.

These interviews will form the basis of my research report. Your name and other identifying information will be kept confidential. You may be quoted in the report, but every effort will be made to keep you from being personally identified. All material collected will be kept either in a locked cabinet or password-protected electronic file. Interview recordings and transcripts will only be available to me, my supervisor Alastair Smith, and a transcriber who has signed a confidentiality agreement. Recordings and transcripts will be destroyed two years after the conclusion of the research. You will be given a copy of the transcript of your own interview to review. You can withdraw from the project at any point before May 10, 2013. If you do, you will not be required to give a reason why. All recordings, transcripts and notes of your interview will be destroyed upon withdrawal.

I will make a summary of the results of this research available to you, if you indicate your interest on the accompanying consent form.

The final report will be submitted for marking to the School of Information Management at Victoria University of Wellington and deposited in the University Library and/or institutional repository. It is intended that this research be used for publication in a scholarly journal and/or a conference presentation or poster.

If you have questions about the research project or procedure, please contact me by phone at 0272048646 or email at burgesnath@myvuw.ac.nz. Alternately, you can contact Alastair Smith at 044635785 or alastair.smith@vuw.ac.nz. Thank you very much. 


\section{Victoria University of Wellington}

\section{Consent to participate in research}

\section{Title of project: 'The communication networks used by special librarians in solo and small libraries'}

I have been given and have understood an explanation of this research project, and I agree to take part in this research.

I have had an opportunity to ask questions and have them answered to my satisfaction. I understand that I may withdraw myself from this project at any time before May 10, 2013, without being required to give a reason why. In this situation any information I have provided will not be used, and the interview recordings, transcriptions, and notes will be destroyed..

I understand that any information I provide will be kept confidential to the researcher, his supervisor and the person who transcribes the recordings of our interview (this person will sign a confidentiality agreement). Any published results will not use my name, and the researcher will make every effort to ensure that any information that can be used to identify me will be omitted before publication. I understand that any recordings and transcriptions of interviews will be kept in a locked cabinet or password-protected file, and will be destroyed two years after the conclusion of the research.

I understand that I will have an opportunity to review the transcript of my interview for information and clarification purposes. I understand that the data I provide will not be used for any purpose other than those outlined in the information sheet, nor will it be released to anyone not named on the information sheet without my written consent.

[ ] Tick this box if you would like to receive a summary of the results of this research when it is completed.

Name (print)

Signed

Date 